\author{
Military Technical College \\ Kobry Elkobbah, Cairo, \\ Egypt.
}

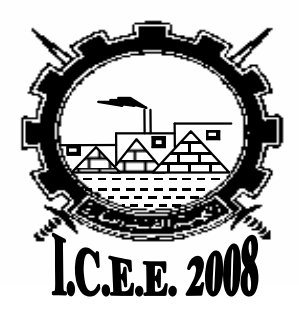

$4^{\text {th }}$ International Conference On Chemical \& Environmental Engineering 27-29 May 2008

\title{
PRODUCTION AND CHARACTERIZATION OF GLASSES AND GLASS-CERAMICS FROM EGYPTIAN IRON SLAG WASTE
}

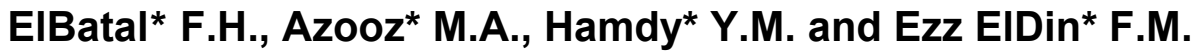

\begin{abstract}
Trials were made for reprocessing Egyptian blast furnace slag with and without additives or commercial batches to produce glasses. Characterization of the crystallization behaviour using differential thermal analysis was carried to find out the best route of preparing glass-ceramic materials and $\mathrm{x}$-ray diffraction studies were done to identify the crystallization phases separated by two steps regime for controlled crystallization. The corrosion behaviours of the prepared glasses and corresponding glass-ceramics by different leaching solutions were done at both room temperature for $1 \& 2$ months and at $95^{\circ} \mathrm{C}$ for 1 hour through the grain method. A further corrosion test inside a gamma-irradiation chamber was carried out for both the reference vitrified slag and the highly promising glass and glass-ceramic samples under direct gamma irradiation facility. Infrared absorption spectra of the prepared samples were measured to identify their structural building units. Scanning electron microscope was used to study the morphology of the prepared samples after corrosion and irradiation.

X-ray diffraction studies indicate the separation of gehlenite and akermanite as major phases in the base slag. On adding some batches of silica and silicate glasses, wollastonite and diopside were separated as main phases. Infrared spectral data confirm these findings. Corrosion studies indicate that the prepared sample containing equal portion of slag and sodium borosilicate batch is the highest durable glass together with its glass-ceramic derivative and the same stability retains under direct exposure to gamma irradiation.
\end{abstract}

KEYWORDS: Iron slag, Glass, Glass-ceramic, Corrosion, Gamma radiation Corresponding author e-mail: fh_elbatal@yahoo.co.uk

\footnotetext{
* National Research Center
} 


\section{INTRODUCTION}

Almost from the dawn of the nuclear age mankind had to face the problem of immobilizing highly radioactive nuclear wastes. Glass was one of the first matrices considered for nuclear waste immobilization. The glass compositions considered have ranged from lead iron phosphate to aluminosilicate to borosilicate glasses. Most countries which are producing high level waste (HLW) have selected borosilicate glass as the preferred waste form [1-3]. The main advantages of the vitrification route include the fact that glass is a good solvent for HLW; glass can be processed at reasonably low temperatures; glass is very tolerant of variations in waste composition; glass exhibits reasonable chemical durability; and exhibits radiation resistant and can accommodate changes occurring during radioactive decay of HLW constituents. Some of the alternatives are the immobilization in crystalline analogue phases [4] such as ceramics or glass-ceramics of variable mineral phases. The choice of wasteform to use for nuclear waste immobilization is a difficult decision and durability is not the sole criterion [4]. The use of industrial wastes as raw materials for glasses and glass-ceramics has gained increasing importance in recent years [59]. The search for inexpensive glass-ceramic materials has been concentrated particularly upon the use of blast furnace slag and natural basaltic rocks [10-14].

This work reports studies to characterize the chemical durability and infrared spectroscopy of the glasses prepared directly only from natural blast furnace slag and that obtained with various additives of some batches of silica and silicate glasses. The work is extended to study the corrosion properties and type of crystalline phases of the glass-ceramic derivatives prepared by two-steps heat treatment regime. Also, the effects of gamma irradiation on corrosion behaviour of both materials have been carried to justify the suitability of the prepared glasses and glass-ceramics to immobilize radioactive wastes.

\section{EXPERIMENTAL DETAILS}

\section{Preparation of Glasses}

The basic reference solid blast furnace slag was provided by Egyptian Iron and Steel Company, Helwan , Cairo, Egypt of the composition shown in Table 1. The base glassy slag was prepared by rapid cooling of its melt and X-ray examination proved of its amorphicity and was pulverized and used as such. The slag without additives was melted in a sillimanite crucible of the Morganite Company, Battersae type (U.K.), for 1 hour in an electrical furnace at $1350^{\circ} \mathrm{C}$ and the melt was poured into a preheated stainless steel plate, and the prepared samples were transferred to a muffle furnace at $450^{\circ} \mathrm{C}$ for annealing to room temperature at a rate of $30^{\circ} \mathrm{C} / \mathrm{h}$. The other studied glasses were prepared by adding different additives as shown in Table 2. All the prepared glassy materials were annealed as described for the reference sample but with the appropriate temperatures.

\section{Differential Thermal Analysis}

DTA was performed in a SETARAM, Labsys tm, TG-DTA-06 model system apparatus in argon atmosphere. A finely- grained sample $(50 \mathrm{mg})$ of the prepared 
base slag glass was studied with $\mathrm{Al}_{2} \mathrm{O}_{3}$ as a reference (Fig. 1). The thermal analysis was conducted within the temperature range $20-1050^{\circ} \mathrm{C}$ with a heating rate of $10^{\circ} \mathrm{C}$.

\section{Preparation of the Corresponding Glass-Ceramics Derivatives}

Bulk specimens of the prepared glasses were converted to their glass-ceramic derivatives by a controlled two-stage crystallization process. The glass samples were heated with a rate of $5^{\circ} \mathrm{C} /$ minute in a muffle furnace up to the nucleation temperature $\left(720^{\circ} \mathrm{C}\right)$ and held for the required time for optimum nucleation ( 3 hours). The nucleated glass was further heated by rising the temperature to the crystallization temperature $\left(930^{\circ} \mathrm{C}\right)$ and held for the required time (3 hours) to complete the crystallization process and the muffle was switched off and the sample was left to cool inside the muffle until room temperature with a rate of $25^{\circ} \mathrm{C} /$ hour.

\section{X-ray Diffraction Measurements}

X-ray diffraction identification of the precipitated crystalline phases was carried out using $\mathrm{Cu}$ Ka radiation with secondary monochromator utilizing a, Brukur D8 Advance (Germany) diffractometer. The working voltage and tube current were $40 \mathrm{Kv}$ and 40 $\mathrm{mA}$, respectively.

\section{Scanning Electron Microscope Measurements}

Scanning electron microscope (SEM) had been used to study the surfaces of the fractured samples of prepared glass and glass-ceramic derivative after combined corrosion and irradiation. An apparatus type JEOL, JXA-840 A (Japan) was used after coating the glass-ceramic surfaces with gold using Edwards S150A sputter coater (England).

\section{Corrosion Studies}

\section{a) At high temperature}

The corrosion behaviour was estimated by calculating the corrosion weight loss (\%) after completion of the immersion time of the glass grains in the specified leaching solution at $95^{\circ} \mathrm{C}$ for 1 hour. This grain method was recommended and applied by several authors [15-17]. $1 \mathrm{gm}$ of the glass grains $(0.3-0.6 \mathrm{~mm}$ diameter) was accurately weighed in a sintered glass crucible of the $\mathrm{G} 4$ Jena type which was placed into a polyethylene beaker $(250 \mathrm{ml}) .150 \mathrm{ml}$ of each leach in solution $(0.1 \mathrm{~N} \mathrm{HCl}, 0.1$ $\mathrm{N} \mathrm{NaOH}$ or distilled water) was introduced to cover the grains. The polyethylene beaker was fitted in a water bath regulated $95^{\circ} \mathrm{C}$ and after 1 hour the beaker was removed from the water bath. The sintered crucible was fitted on a suction pump and the whole solution was pumped through it. The sintered crucible was transferred to an air oven at $120^{\circ} \mathrm{C}$ for 1 hour.

\section{b) At room temperature}

$1 \mathrm{gm}$ of the grains was placed in a sintered glass crucible $\mathrm{G} 4$ in a polyethylene beaker $(250 \mathrm{ml})$ and $150 \mathrm{ml}$ of the leaching solution $(0.1 \mathrm{~N} \mathrm{HCl}, 0.1 \mathrm{~N} \mathrm{NaOH}$, distilled 
water) was introduced to cover the grains. After $1 \& 2$ months, the crucibles were fitted on a suction pump and the whole solution was pumped through the crucible. The crucible was dried in oven at $120^{\circ} \mathrm{C}$ for 1 hour. The loss was calculated.

\section{c) Corrosion in direct radiation chamber}

Glasses Nos.1\&7 and their corresponding glass ceramics were chosen for this harsh environment study because they represent the base glassy slag and the glass that shows the highest durability data in both corrosion measurements at room temperature and at $95^{\circ} \mathrm{C}$.

Each glass or glass-ceramic sample was transferred into a pure silica beaker (200 $\mathrm{mL}$ ). Then $150 \mathrm{~mL}$ deionized water was added, with air head space of $\sim 0.4 \mathrm{~cm}$, and the beakers were closed tightly and were exposed together to different irradiation doses emitted from a Canadian ${ }^{60} \mathrm{Co}$ (Ci 2000) with dose rate $1 \times 10^{-4} \mathrm{~Gy} / \mathrm{s}$. The given doses were $20,40,65,80$ and $105 \mathrm{kGy}$.

\section{Infrared Absorption Measurements}

Infrared absorption spectra of glasses and their corresponding glass ceramics were measured in the wavenumber range $\left(2000-400 \mathrm{~cm}^{-1}\right)$ at resolution $2 \mathrm{~cm}^{-1}$ using a Fourier Transform Infrared Spectrometer (type Jasco FT/IR-430, Japan).

\section{RESULTS}

\section{Corrosion Studies at low temperature $\left(\sim 20^{\circ} \mathrm{C}\right)$ for $1 \& 2$ months}

Table 3. depicts the weight loss $\%$ and data indicate the following parameters:

(1) $\mathrm{HCl}$ leaching medium is more corrosive than the other leaching solvents of alkaline $\mathrm{NaOH}$ solution and distilled water, the latter is almost ineffective and does not show any marked corrosion on the studied glasses.

(2) It is apparent that increasing both the percent of $\mathrm{SiO}_{2}$ and $\mathrm{Na}_{2} \mathrm{O}$ to $15 \mathrm{wt} \%$ in the slag composition decreases the chemical durability of the base melted slag while further additions up to $20 \mathrm{wt} \%$ of both oxides improve the durability and decrease the corrosion weight loss values. The addition of $\mathrm{SiO}_{2}(27.5 \%)+\mathrm{TiO}_{2}(2 \%)+\mathrm{CaF}_{2}$ $(0.5 \%)$ improves the durability of the slag glass.

(3) The obvious beneficial chemical improvement is obtained by the addition of equal batches of either soda lime silica or soda borosilicate glasses to the same melt slag. The latter glass is the most efficient in the improvement process towards the action of all leaching solutions.

(4) A slight increase in the weight loss \% data after two months of immersion than that obtained after immersion for one month and especially quite observed with $\mathrm{HCl}$ as a leaching solution while other solutions reveal saturation or constancy.

(5) The values of weight loss \% data show remarkable decrease for the glass-ceramic samples than their glassy samples for all leaching solutions under the used conditions. 


\section{Corrosion Studies at high temperature $\left(95^{\circ} \mathrm{C}\right)$ for 1 hour}

Table 4. indicates the following parameters:

(a) It is obvious that $\mathrm{HCl}$ solution $(0.1 \mathrm{~N})$ corrodes the samples while $\mathrm{NaOH}(0.1 \mathrm{~N})$ and distilled water have no visual effects on them.

(b) The corrosion by $\mathrm{HCl}$ solution changes with the change in the glass constituents. The corrosion increases first by the introduction of $10 \mathrm{gms}$ of both $\mathrm{Na}_{2} \mathrm{O}+\mathrm{SiO}_{2}$ and then decreases with more additions (15 or $20 \mathrm{gms}$ ).

Also, the addition of commercial batches of either soda-lime silica or sodaboric oxide-silica improves the resultant glasses towards the acid corrosion.

(c) The glass-ceramic derivatives show as expected better chemical durability towards acid solution than the base glasses.

(d) It is evident that the prepared glassy sample No. (7) possesses superior durability either in the glassy form or as glass-ceramic derivative.

\section{Corrosion results in direct radiation chamber}

Table 5. reports the values of the weight loss \% for either glass or glass-ceramic Nos. ( $\mathrm{G} 1$ and $\mathrm{G} 7$ ) when they were immersed in deionized water and exposed directly to different irradiation doses $(20,40,65,80$ and $105 \mathrm{kGy})$. The data indicate that gamma irradiation leads to slight increase in the weight loss \% for these two samples. It is obvious that successive irradiation doses causes a slight increase in the weight loss \% but soon reach constancy and the glass-ceramic derivatives are more resistant than the original glasses.

\section{DTA Results}

Fig. 1 shows the DTA of the parent glass (No. 1), it can be seen that a nucleation temperature of $725^{\circ} \mathrm{C}$ and crystallization temperature at $937^{\circ} \mathrm{C}$ are recorded.

\section{X-ray Diffraction Measurements of Glass Ceramic Derivatives}

The X-ray diffraction patterns (Fig. 2) show that the base slag glass-ceramic consists of gehlenite $\left(\mathrm{Ca}_{2} \mathrm{Al}_{2} \mathrm{SiO}_{7}\right.$, card number $\left.35-0755\right)$ and akermanite $\left(\mathrm{Ca}_{2} \mathrm{MgSi}_{2} \mathrm{O}_{7}\right.$, card number 35-0592) as the main crystalline phases and also diopside $\left(\mathrm{CaMg}\left(\mathrm{SiO}_{3}\right)_{2}\right.$, card number 11-654) as minor crystalline phase.

By adding excess of $\mathrm{Na}_{2} \mathrm{O}$ and $\mathrm{SiO}_{2}$ to slag base sample, as in sample (2), the X-ray diffraction patterns show the formation of a new crystalline phase (wollastonite-1A $\left(\mathrm{CaSiO}_{3}\right.$, card number 42-547). By adding more $\mathrm{Na}_{2} \mathrm{O}$ and $\mathrm{SiO}_{2}$ as in samples $(3,4)$, the crystalline diopside phase disappears while the crystalline phase wollastonite-1A becomes more prominent. For sample (5), where $\mathrm{CaF}_{2}$ and $\mathrm{TiO}_{2}$ additives were added beside silica, the X-ray diffraction patterns were different from that of base sample. The main crystalline phase is wollastonite-1A $\left(\mathrm{CaSiO}_{3}\right.$, card number 42-547) and there is also diopside $\left(\mathrm{CaMg}\left(\mathrm{SiO}_{3}\right)_{2}\right.$, card number 11-654) as a minor phase. The gehlenite and akermanite phases were not quite identified as appeared from $X$ ray diffraction results. For sample (6), where equal weight of a soda lime silica batch was added, the X-ray diffraction patterns show the formation of wollastonite-1A as the main crystalline phase with the formation of diopside as a minor phase. In the case of sample (7), where equal weight of a soda borosilicate batch was added, the 
X-ray diffraction patterns show well matching with the crystalline phase wollastonite$1 \mathrm{~A}$ as the major phase and also the existence of akermanite as a minor phase.

\section{Infrared Absorption Spectroscopy of Glasses and Glass Ceramic Derivatives}

The infrared absorption spectra of the slag glass samples (Fig. 3) nearly resemble the spectra of commercial soda lime silica glasses with the following parameters: (a) a main strong band at about $1025 \mathrm{~cm}^{-1},(\mathrm{~b})$ undefined bands at $1114 \mathrm{~cm}^{-1}$ and 928 $\mathrm{cm}^{-1}$, (c) medium band at $681 \mathrm{~cm}^{-1}$, and (d) a strong band at $459 \mathrm{~cm}^{-1}$. The undefined band at $928 \mathrm{~cm}^{-1}$ is observed to be more defined and increases in intensity by increasing $\mathrm{Na}_{2} \mathrm{O}$ content in samples $\left(2,3\right.$, and 4). The top of the band at $681 \mathrm{~cm}^{-1}$ shifts to higher wavelength (about $725 \mathrm{~cm}^{-1}$ ) by increasing the content of silica. By converting the slag glasses into their glass-ceramics derivatives, the main IR bands at $1025 \mathrm{~cm}^{-1}, 928 \mathrm{~cm}^{-1}, 700 \mathrm{~cm}^{-1}, 455 \mathrm{~cm}^{-1}$ show splitting into several component peaks according to the formed crystalline phases as shown in (Fig. 4).

\section{DISCUSSION}

\section{Routes of Glass-Ceramics from Slag Wastes}

The versatility of the glass-ceramics production process is manifested by the many wastes that have been used as raw materials for glass-ceramics, which include coal fly ash [18] mud from zinc hydrometallurgy [19], slag from steel production [7, 20-23], ash and slag from waste incinerators [24, 25] and mud from alumina production [26], electric arc furnace and foundary sands [27] as well as cement kiln dust [28]. Much work has been carried out on the immobilization of nuclear waste in glass and ceramic matrices and recently there has been some interest in the use of glassceramic matrices for this purpose [29, 30]. Blast furnace slag was the first silicate waste to be thoroughly investigated as a source material for glass-ceramics [31]. The first prepared "slagceram" was produced by conventional two-stage heat treatment method [31]. The addition of low titania (2-5 wt $\left.\% \mathrm{TiO}_{2}\right)$ was observed to show surface crystallization as the predominant mechanism of glass-ceramic formation [32] while with extra $\mathrm{TiO}_{2}$, bulk crystallization was the main mechanism. At low crystallization temperature of $950^{\circ} \mathrm{C}$, crystallization was not complete and only small amounts of gehlenite $\left(\mathrm{Ca}_{2} \mathrm{Al}_{2} \mathrm{SiO}_{7}\right)$ and merwinite $\left(\mathrm{Ca}_{3} \mathrm{Mg}\left(\mathrm{SiO}_{4}\right)_{2}\right)$ were formed. At $1100^{\circ} \mathrm{C}$, the main crystalline phase of the slag-based glass-ceramic with $\mathrm{TiO}_{2}$ was a melilite solid solution, containing gehlenite and akermanite $\left(\mathrm{CaMgSi}_{2} \mathrm{O}_{7}\right)$.

Recent work on slag glass-ceramics using a single-stage heat-treatment method was reported by Francis [33]. The identified crystalline phases in the glass-ceramics were gehlenite, diopside and $\mathrm{BaAl}_{2} \mathrm{Si}_{2} \mathrm{O}_{8}$, the morphology of the gehlenite and $\mathrm{BaAl}_{2} \mathrm{Si}_{2} \mathrm{O}_{8}$ tended to be acicular or rod-like whereas the diopside was dendritic.

\section{Corrosion Behaviour of Multicomponent Silicate glasses}

It was early suggested that glass-water (or aqueous solution) reactions can be considered to proceed in two stages in silicate glasses [34]:

Stage 1: The initial stage of attack involves ion exchange between alkali ions from the glass and hydrogen or hydronium ions from the immersion solution. During this early stage the remaining constituents of the glass are not altered and a leached 
layer depleted in alkali ions is formed. The rate of alkali extraction from the glass is primarily parabolic in character and controlled by the diffusion of ions involved through the leached layer. In order to maintain electrical neutrality, hydrogen $\left(\mathrm{H}^{+}\right)$ ions or hydronium $\left(\mathrm{H}_{3} \mathrm{O}^{+}\right)$ions must diffuse from the immersion solution into the glass surface and occupy those sites vacated by the sodium ions.

Stage 2: The second stage of attack is a process by which the destruction and dissolution of the leached surface layers on the bulk glasses occur. The rate of dissolution is controlled by a surface reaction.

At least three reactions are suggested to explain the proposed mechanisms for chemical corrosion in silicate glasses:

$$
\begin{aligned}
& \equiv \mathrm{Si}-\mathrm{O}-\mathrm{R}^{+}+\mathrm{H}_{3} \mathrm{O}^{+} \rightarrow \text { ISi-OH }+\mathrm{R}^{+}+\mathrm{H}_{2} \mathrm{O} \\
& \text { ( } R \text {, modifier alkali) } \\
& \text { =Si-O-Si }=+\mathrm{H}_{2} \mathrm{O} \rightarrow \text { ESi-OH }+\mathrm{HO}-\mathrm{Si} \equiv \\
& \equiv \mathrm{Si}-\mathrm{O}-\mathrm{R}^{+}+\mathrm{H}_{2} \mathrm{O} \rightarrow \mathrm{ESi}-\mathrm{OH}+\mathrm{R}^{+}+\mathrm{OH}^{-}
\end{aligned}
$$

The experimental corrosion results can be interpreted as follows:

(1) The corrosion mechanism proceeds in acidic solution (and distilled water) through ion exchange process including the liberation of modifiers (alkali and alkaline earth ions) from the surface of the glass into the solution and their replacement by hydrogen (or hydronium) ions. This behavior seems to proceed with a high rate at first and then is changed due to several possible factors outlined as follows:

(a) The outermost alkali or alkaline earth ions on the surface of the glass are depleted and take more time and longer distance for the corroding solution to reach the inner alkali ions to be further released in the solution.

(b) The probability of the formation of insoluble gel layers or precipitates which retard the continuous progress of the corrosion process through the specified channels for diffusion as proposed by Greaves [35].

(c) The possible alteration of the structural network arrangement as proposed by Bunker et al [49] by reorganization or polymerization.

(2) Hydrochloric acid solution $(0.1 \mathrm{~N})$ is observed to show relatively high corrosion than sodium hydroxide $(0.1 \mathrm{~N})$ or distilled water with all the studied glassy samples because the modifier ions are known to be easily and highly soluble in $\mathrm{HCl}$ solution after being detached during the ion-exchange process. $\mathrm{HCl}$ is known to highly ionized relative to weakly ionized water.

(3) Sodium hydroxide solution $(0.1 \mathrm{~N})$ is expected to produce sparingly soluble hydroxides or precipitates upon reacted with many oxides such as: $\mathrm{CaO}$, $\mathrm{Al}_{2} \mathrm{O}_{3}, \mathrm{MnO}, \mathrm{Fe}_{2} \mathrm{O}_{3}$.

(4) The first high corrosion weight loss $\%$ on introducing $10 \%$ of both $\mathrm{SiO}_{2}$ and $\mathrm{Na}_{2} \mathrm{O}$ to the base slag and the improvement of durability when $20 \%$ of both oxides can be realized and interpreted as follows. When $15 \%$ or $20 \%$ of $\mathrm{SiO}_{2}$ and $\mathrm{Na}_{2} \mathrm{O}$ are added to the slag, the chemical compositions obtained are varied and the final products contain higher content of both constituents. The resultant compositions contain modifier $\mathrm{Na}^{+}$ions in double quantity to the silica $\mathrm{Si}^{4+}$ ions. It is expected that the released alkali ions from the ionic exchange process are higher and thus the corrosion is more pronounced. On reaching the addition to $20 \%$ of both $\mathrm{SiO}_{2}$ and $\mathrm{Na}_{2} \mathrm{O}$, it seems that the amount of silica reaches a level favorable to build up structural $\mathrm{SiO}_{4}$ units to make the structure 
shows some resistance to the attacking solution. This behavior is aided by the presence of other oxides such as $\mathrm{Al}_{2} \mathrm{O}_{3}$ and $\mathrm{CaO}$ which naturally improve the durability.

(5) The relatively high resistance to corrosion of samples 5,6 and 7 can be related primarily to the change in the chemical composition through the introduction of less corroded partners. Sample no.7 shows the least corroded data in all solutions because of the introduction of equal batch of known high resistant borosilicate composition to the base slag which produces a compact structure in which the modifiers are attached as charge compensators to some building units such as $\mathrm{AlO}_{4}$ and $\mathrm{BO}_{4}$ groups.

(6) The high durability observed in the glass-ceramic derivatives is realized by considering the well-organized microcrystalline structures were found after complete crystallization. The obtained microcrystalline derivatives with specific definite boundaries are known to possess high chemical durability than their parent amorphous glasses.

\section{Effect of combined corrosion and irradiation}

It was shown that [36] the rates of alkali ion exchange have a non-Arhenius behavior depending both on irradiation dose and dose rate. For this reason some effects cannot be simulated by external irradiation and requires in situ measurements.

Radiation effects are of important consideration because of the potential influence on glass corrosion stability [37].

The present results obtained from representative glass and glass-ceramic indicate that progressive gamma-irradiation cause slight continuous increase in the corrosion weight loss and this seems to be understood by the following explanations.

The main result of $\mathrm{y}$-irradiation is the formation of point defects in the glass. Classification of point defects in irradiated silicate glasses is based and resembles those in silica glass. There are two types of point defects in irradiated silica glasses [36-38]: oxygen-deficiency defects are neutral oxygen vacancies and paramagnetic E' centers. These are schematically represented as $\equiv \mathrm{Si}-\mathrm{Si} \equiv$ and $\equiv \mathrm{Si} \bullet$ respectively, where • depicts an unpaired spin residing on silicon, and oxygen-excess defects in silica glass are the NBO hole center and the peroxy radical. These are schematically represented as $\equiv \mathrm{Si}-\mathrm{O} \bullet$ and $\equiv \mathrm{Si}-\mathrm{O}-\mathrm{O} \bullet$ [38]. The most important point defects in alkali silicate glasses are oxygen-excess centers [38]. There are two types of NBO hole centers in silicate glasses, one is an analogue to a NBOs on the same silicon. The NBO hole centers are formed by irradiation-chemical reaction:

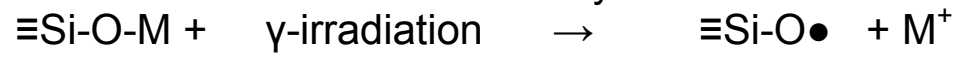

It is assumed that a free hole resulting from the gamma-irradiation is first trapped at the $=\mathrm{Si}-\mathrm{O}-\mathrm{M}$ site and then the alkali ion is free to diffuse away to the site of a trapped electron where it stabilizes the uncompensated charge [38]. Moreover, ionizing radiation excites electrons, which leads to ionization of water molecules and dissolved gases to form reactive radicals and new molecules (radiolysis). These radiolytic products, such as nitric acid, carboxylic acid, ${ }^{\circ} \mathrm{OH}$ and $\mathrm{O}^{2-}$, can influence the glass corrosion.

The results show that the effects of radiation on the glass corrosion varies depending on the corrosion conditions, because they are quite complex due to interactions between the dissolving glass constituents, and buffering capacity of solution against radiolytically produced acids [39]. Hence $\mathrm{Y}$-irradiation provides an important input to 
ion exchange due to releasing alkali ions through radiochemical reaction (4), which makes alkali ions much more mobile and ready for ion exchange.

\section{Infrared Absorption Spectroscopy of Glassy Samples}

The infrared absorption peaks at $1114 \mathrm{~cm}^{-1}$ and $1024 \mathrm{~cm}^{-1}$ are assigned to the asymmetric stretching vibrations of the silicate tetrahedral network. The undefined peak at about $930 \mathrm{~cm}^{-1}$ is assigned to the $\mathrm{Si}^{-}$stretching vibration with non-bridging oxygen (NBO). The content of the NBO in the glass is increased by the increase of the alkali and alkaline earth oxides such as sodium and calcium. In samples (2, 3 and $4)$, the content of sodium oxide increases in relative to the former oxide $\left(\mathrm{SiO}_{2}\right)$ and consequently the amount of NBO increases. Therefore, the undefined peak at 930 $\mathrm{cm}^{-1}$ becomes more prominent by increasing sodium oxide. The addition of silica ( 27.5 wt \%) without sodium oxide for sample 5 decreases the intensity of the peak than the base sample 1 which indicates that the content of NBO is decreased. The addition of high silica 74 wt\% silica in samples 6 and 7 against small amounts of modifiers results in the weakness of the peak due to the continuous decreasing of NBO content.

The weak band at $\left(800-600 \mathrm{~cm}^{-1}\right)$ can be assigned to Si-O-Si symmetric stretching of bridging oxygens between tetrahedral. By increasing the silica content in the other samples, this peak shifts to higher wavenumbers. Merzbacher et Al. [40] reported that infrared spectra of aluminosilicate glasses show a shift of the stretching mode to longer wavenumber with increasing Al/Si ratio. The increase of the silica content in samples other than the base sample make the Al/Si ratio decrease and so, the peak is seen to shift to the higher energy. The band at $600-400 \mathrm{~cm}^{-1}$ in the base sample can be assigned to the bending motions of the aluminosilicate network.

\section{Infrared Spectra of Glass-Ceramics}

The absorption bands between $1150 \mathrm{~cm}^{-1}$ and $900 \mathrm{~cm}^{-1}$ can be assigned to stretching vibrations of silicate tetrahedra with bridging oxygens and non-bridging oxygens. Other absorption bands which are observed between 700 and $400 \mathrm{~cm}^{-1}$ can be assigned to O-Si-O bending modes.

By comparing the IR absorption peaks of samples with the IR absorption peaks of gehlenite, melilite, diopside and wollastonite (the crystalline phases proved to be existed in the studied glass-ceramics by X-ray diffraction) [41], it can be concluded that:

1- For sample 1, the IR peaks belong mainly to gehlenite and melilite groups.

2- The samples 2, 3, and 4 show the same behaviour as sample 1.

3- For samples 5, 6, and 7, the IR peaks are matched with peaks of wollastonite and diopside crystalline phases. The characteristic strong peak at about 905$899 \mathrm{~cm}^{-1}$ of wollastonite is present in all these samples $(5,6 \& 7)$ while it is not present in the other samples.

\section{Scanning Electron Microscopy Data}

The leached layers of most samples are still intact showing quite resistance to corrosion (Fig. 5), but in a few specimens with low $\mathrm{SiO}_{2}$ content, it is partially cracked (figure 6). There are two feasible explanations for the destruction of the leached layer: (a) the resulting change in the density of the outmost glass layers together with 
variations of temperature of the acidic solution, or (b) the outgassing of $\mathrm{H}_{2} \mathrm{O}$ molecules by applying a high vacuum during the SEM investigations.

\section{CONCLUSION}

The crystallization behaviors of multicomponent glasses prepared from the mixing of blast furnace slag with additives or nucleating agents or commercial glass batches were studied. X-ray diffraction patterns indicate the formation of gehlenite and akermanite as major phases in the base blast furnace slag glass-ceramic but change to wollastonite and diopside with additives. Infrared absorption spectra confirm the presence of silicate units of approximately comparable structure. Chemical corrosion studies show that the prepared glassy samples reveal resistance to alkaline solution and water and their glass-ceramic derivatives possess better durabilities. The glass and glass-ceramic derivative containing equal portions of iron slag and borosilicate batch show the highest chemical corrosion even under direct gamma irradiation and can thus find application as host material for immobilization of radioactive wastes.

\section{REFERENCES}

[1] Lutz, W. and Ewing, R.C., " Radioactive Waste Forms for the Future”, NorthHolland, Amsterdam (1988).

[2] Donald, I.W., Metcalfe, B.L. and Taylor, R.N.J. "The Immobilization of High Level Radioactive Wastes Using Ceramics and Glasses", Journal of Materials Science, 32 (22) 5851-5887 (1997).

[3] Plodinec, M.J., "Borosilicate Glasses for Nuclear Waste Imobilisation", Glass Technology, 41 (6) 186-192 (2000).

[4] a) Lee, W.E., Ojovan, M.I., Stennett,M.C., Hyatt, N.C., "Immobilization of Radioactive Waste in Glasses, Glass Composite Materials and Ceramics", Advances in Applied Ceramics, 105 (1) 3-12 (2006).

b) Ojovan, M.I. and Batyukhnova, O.G., "Glasses for Nuclear Waste Immobilization", WM' 07 Conference, February 25-1 March, 2007, Tucson, Arizona (2007).

[5] Romero, M. and Rincon,J.M., "Surface and Bulk Crystallization of Glass-Ceramic in the $\mathrm{Na}_{2} \mathrm{O}-\mathrm{CaO}-\mathrm{ZnO}-\mathrm{PbO}-\mathrm{Fe}_{2} \mathrm{O}_{3}-\mathrm{Al}_{2} \mathrm{O}_{3}-\mathrm{SiO}_{2}$ System Derived from a Goethite Waste", Journal of the American Ceramic Society, 82 (5) 1313-1317 (1999).

[6] Karamanov, A., Taglieri, G. and Pelino, M., "Iron-Rich Sintered Glass-Ceramics from Industrial Wastes", Journal of the American Ceramic Society, 82 (11) 30123016 (1999).

[7] Romero, M., Rawlings, R.D. and Rincon, J.M.

a) "Development of a New Glass-Ceramic by Means of Controlled Vitrification and Crystallisation of Inorganic Wastes from Urban Incineration", Journal of the European Ceramic Society, 19 (12) 2049-2058 (1999).

b) "Crystal Nucleation and Growth in Glasses from Inorganic Wastes from Urban Incineration", Journal of Non-Crystalline Solids, 271 (1-2) 106-118 (2000).

[8] Ferreira, E.B., Zanotto, E.D.and Scudella,A.M., "Glass and Glass-Ceramic from Basic Oxygen Furnace (BOF) Slag", Glass Sci. Technol., 75 (2) 75-86 (2002). 
[9] Francis, A.A. "Non-Isothermal Crystallization Kinetics of a Blast Furnace Slag Glass", Journal of the American Ceramic Society, 88 (7) 1859-1863 (2005).

[10] Berezhoni, A.I., Glass-Ceramics and Photo-Sitalls, Plenum Press, New York (1970).

[11] Beall, G.H. and Rittler, L., Amer. Ceram. Soc. Bull., 55 579-582 (1975).

[12] Strnad, Z., Glass-Ceramic Materials, Elsevier Science, Amsterdam (1986).

[13] Boccaccini, A.R., Bucker, J. and Bossert, J., "Glass and Glass-Ceramics from Coal Fly-Ash and Waste Glass", Tiles\& Brick Int., 12 (6) 508-515 (1996).

[14] Boccaccini, A.R., Köpf, M.and Stumpfe, W., "Glass-Ceramics from Filter Dusts from Waste Incinerators", Ceramics International, 21 (4) 231-235 (1995).

[15] Newton, R.G., "The Durability of Glass", Glass Technology, 26 (1) 21-38 (1985).

[16] Khedr A.A. and ElBatal, H.A. "Corrosion of Zinc-Containing Cabal Glasses by Various Leaching Solutions", Journal of the American Ceramic Society, 79 (3) 733-741 (1996).

[17] ElBadry, K.M., Moustafa, F.A., Azooz, M.A. and ElBatal, F.H."Corrosion Behaviour of Some Selected Bioglasses by Different Aqueous Solutions", Glass Technology, 43 (4) 162-170 (2002).

[18] Kumar, S., Singh, K.K. and Ramachandrarao, P., ."Synthesis of Cordierite from Fly Ash and its Refractory Properties", Journal of Materials Science Letters, 19 (14) 1263-1265 (2000).

[19] Montanaro, L., Bianchini, N., Rincon, J.M. and Romero, M., "Sintering Behaviour of Pressed Red Mmud Wastes from Zinc Hydrometallurgy", Ceramics International, 27 (1) 29-37 (2001).

[20] Torping, J.A., J. Can. Ceram. Soc., 4563 (1976).

[21] Ahmed A.A.and Abbas, A.F., "Does Blast Furnace Slag Improve Glassmaking?", Glass Ind., December, 15 (1984).

[22] Pouton, C.B., Rawlings R.D. and Rogers, P.S., Proc. Brit. Ceram. Soc., 27229 (1986).

[23] Khater, G.A. "The Use of Saudi Slag for the Production of Glass-Ceramic Materials", Ceramics International, 28 (1) 59-67 (2002).

[24] Rincon, J.M., Romero M.and Boccaccini, A.R., "Microstructural Characterisation of a Glass and a Glass-Ceramic Obtained from Municipal Incinerator Fly Ash", Journal of Materials Science, 34 (18) 4413-4423 (1999).

[25] Stoch, L., "Homogeneity and Crystallisation of Vitrified Municipal Waste Incineration Ashes", Glass Technology, 45 (2) 71-73 (2004).

[26] Zhang, P. and Yan, J., Z. Metallk, 91764 (2000).

[27] Gao, Z.and Drummond III, C.H., "Thermal Analysis of Nucleation and Growth of Crystalline Phases in Vitrified Industrial Wastes", Journal of the American Ceramic Society, 82 (3) 561-565 (1999).

[28] Morsi, M.M., Khater, G.A. and Range, K.J. "Glass Ceramics in the System Diopside-Anorthite-Orthoclase Prepared by Using Some Industrial Waste Materials", Glass Technology, 42 (6) 160-164 (2001).

[29] Raman, S.V., "Microstructures and Leach Rates of Glass-Ceramic Nuclear Waste Forms Developed by Partial Vitrification in a Hot Isostatic Press", Journal of Materials Science, 33 (7) 1887-1895 (1998).

[30] Loiseau, P., Caurant, D., Baffier, N., Mazerolles, L. and Fillet, C., " GlassCeramic Nuclear Waste forms Obtained from $\mathrm{SiO}_{2}-\mathrm{Al}_{2} \mathrm{O}_{3}-\mathrm{CaO}-\mathrm{ZrO}_{2}-\mathrm{TiO}_{2}$ Glasses Containing Lanthanides ( $\mathrm{Ce}, \mathrm{Nd}, \mathrm{Eu}, \mathrm{Gd}, \mathrm{Yb}$ ) and actinides (Th): Study of Internal Crystallization", Journal of Nuclear Materials, 335 (1) 14-32 (2004). 
[31] Davies, M.W., Kerrison, B., Gross,W.E., Robson, W.J. and Wiebell, D.F., J. Iron Steel Institute, 208348 (1970).

[32] Ovecoglu, M.L., "Microstructural Characterization and Physical Properties of a Slag-Based Glass-Ceramic Crystallized at 950 and $1100{ }^{\circ} \mathrm{C}$ ", Journal of the European Ceramic Society, 18 (2) 161-168 (1998).

[33] Francis, A.A., "Conversion of Blast Furnace Slag into New Glass-Ceramic Material", Journal of the European Ceramic Society, 24 (9) 2819-2824 (2004).

[34] Clark, D.E., Pantano, C.G. and Hench, L.L., "Corrosion of Glass", Magazines for Industry, New York (1979).

[35] Greaves, G.N., "EXAFS for Studying Corrosion of Glass Surfaces", Journal of Non-Crystalline Solids, 120 (1-3) 108-116 (1990).

[36] Ojovan, M.I. and Lee, W.E., "Alkali Ion Exchange in Y-Irradiated Glasses", Journal of Nuclear Materials, 335 (3) 425-432 (2004).

[37] Wronkeiewiez, D.J., Mater. Res. Soc. Symp. Proc., 46583 (1994).

[38] Weber, W.J., Ewing, R.C., Angell, C.A., Arnold, G.W., Cormack, A.N., Delaye, J.M., Gscom, D.L., Hobbs, L.W., Navrotsky, A., Price, D.L., Stoneham, A.M. and Weinberg, M.C. "Radiation Effects in Glasses Used for Immobilization of High-Level Waste and Plutonium Disposition", Journal of Materials Research, 12 (8) 1946-1978 (1997).

[39] Skuja, L., "Optically Active Oxygen-Deficiency-Related Centers in Amorphous Silicon Dioxide", Journal of Non-Crystalline Solids, 239 (1-3) 16-48 (1998).

[40] Merzbacher, C.I. and White, W.B., "The Structure of Alkaline Earth Aluminosilicate Glasses as Determined by Vibrational Spectroscopy", Journal of Non-Crystalline Solids, 130 (1) 18-34 (1991).

[41] Gadsden, J.A., Infrared Spectra of Minerals and Related Inorganic Compounds", Butterworths, London (1975). 
Table 1. Chemical composition of blast furnace slag (wt \%)

\begin{tabular}{|c|c|}
\hline Oxide & Percent \\
\hline $\mathrm{SiO}_{2}$ & 38.21 \\
\hline $\mathrm{Al}_{2} \mathrm{O}_{3}$ & 10.45 \\
\hline $\mathrm{Fe}_{2} \mathrm{O}_{3}$ & 1.27 \\
\hline $\mathrm{CaO}$ & 37.70 \\
\hline $\mathrm{MgO}$ & 2.05 \\
\hline $\mathrm{MnO}$ & 3.50 \\
\hline $\mathrm{Na}_{2} \mathrm{O}$ & 1.61 \\
\hline $\mathrm{K}_{2} \mathrm{O}$ & 0.71 \\
\hline $\mathrm{SO}_{3}$ & 3.52 \\
\hline $\mathrm{L.O} . \mathrm{I}$ & 0.43 \\
\hline
\end{tabular}

Table 2. Chemical composition of the prepared glassy samples investigated

\begin{tabular}{|c|c|c|c|c|c|}
\hline $\begin{array}{l}\text { Glass } \\
\text { No. }\end{array}$ & $\begin{array}{l}\text { Slag quantity } \\
\text { (gm) }\end{array}$ & \multicolumn{4}{|c|}{ Additions (gm) } \\
\hline 1 & Pure slag & - & - & - & - \\
\hline 2 & 100 & $10 \mathrm{Na}_{2} \mathrm{O}$ & $10 \mathrm{SiO}_{2}$ & - & - \\
\hline 3 & 100 & $15 \mathrm{Na}_{2} \mathrm{O}$ & $15 \mathrm{SiO}_{2}$ & - & - \\
\hline 4 & 100 & $20 \mathrm{Na}_{2} \mathrm{O}$ & $20 \mathrm{SiO}_{2}$ & - & - \\
\hline 5 & 100 & - & $27.5 \mathrm{SiO}_{2}$ & $2 \mathrm{TiO}_{2}$ & $0.5 \mathrm{CaF}_{2}$ \\
\hline 6 & 100 & \multicolumn{4}{|c|}{$\begin{array}{c}100 \text { (batch soda lime silica glass } 16 \mathrm{wt} \% \mathrm{Na}_{2} \mathrm{O}, 10 \mathrm{wt} \% \\
\left.\mathrm{CaO}, 74 \mathrm{wt} \% \mathrm{SiO}_{2}\right)\end{array}$} \\
\hline 7 & 100 & \multicolumn{4}{|c|}{$\begin{array}{c}100 \text { (batch soda borosilicate glass } 16 w t \% \mathrm{Na}_{2} \mathrm{O} \text {, } \\
10 \mathrm{wt} \% \mathrm{~B}_{2} \mathrm{O}_{3}, 74 \mathrm{wt} \% \mathrm{SiO}_{2} \text { ) }\end{array}$} \\
\hline
\end{tabular}


Table 3. Weight loss \% data of the studied glasses and their glass-ceramic derivatives samples at room temperature $\left(20^{\circ} \mathrm{C}\right)$ for $1 \& 2$ months

\begin{tabular}{|c|c|c|c|c|c|}
\hline \multirow{3}{*}{$\begin{array}{c}\text { Glass } \\
\text { No. }\end{array}$} & $\begin{array}{c}\text { Leaching } \\
\text { media }\end{array}$ & $\begin{array}{c}\text { Wt loss \% } \\
\text { (1 month) } \\
\text { immersion }\end{array}$ & $\begin{array}{c}\text { Wt loss \% } \\
\text { (2 month) } \\
\text { immersion }\end{array}$ & $\begin{array}{c}\text { Wt loss \% } \\
\text { (1 month) } \\
\text { immersion }\end{array}$ & $\begin{array}{c}\text { Wt loss \% } \\
\text { (2 month) } \\
\text { immersion }\end{array}$ \\
\hline \multirow{4}{*}{1} & $\mathrm{HCl}$ & 14.28 & 14.28 & 12.28 & 12.28 \\
\cline { 2 - 6 } & $\mathrm{NaOH}$ & 0.04 & 0.04 & 0.03 & 0.03 \\
\cline { 2 - 6 } & $\mathrm{H}_{2} \mathrm{O}$ & 0.00 & 0.00 & 0.00 & 0.00 \\
\hline \multirow{4}{*}{2} & $\mathrm{HCl}$ & 23.78 & 23.78 & 20.78 & 20.00 \\
\cline { 2 - 6 } & $\mathrm{NaOH}$ & 0.07 & 0.07 & 0.05 & 0.06 \\
\cline { 2 - 6 } & $\mathrm{H}_{2} \mathrm{O}$ & 0.00 & 0.00 & 0.00 & 0.00 \\
\hline \multirow{4}{*}{3} & $\mathrm{HCl}$ & 28.70 & 28.70 & 25.70 & 25.72 \\
\cline { 2 - 6 } & $\mathrm{NaOH}$ & 0.24 & 0.24 & 0.20 & 0.21 \\
\cline { 2 - 6 } & $\mathrm{H}_{2} \mathrm{O}$ & 0.00 & 0.00 & 0.00 & 0.00 \\
\hline \multirow{4}{*}{4} & $\mathrm{HCl}$ & 9.12 & 9.12 & 7.12 & 7.12 \\
\cline { 2 - 6 } & $\mathrm{NaOH}$ & 0.29 & 0.29 & 0.24 & 0.37 \\
\cline { 2 - 6 } & $\mathrm{H}_{2} \mathrm{O}$ & 0.03 & 0.03 & 0.01 & 0.02 \\
\hline \multirow{3}{*}{5} & $\mathrm{HCl}$ & 6.28 & 6.28 & 4.28 & 6.00 \\
\cline { 2 - 6 } & $\mathrm{NaOH}$ & 0.89 & 0.89 & 0.85 & 0.99 \\
\cline { 2 - 6 } & $\mathrm{H}_{2} \mathrm{O}$ & 0.00 & 0.00 & 0.00 & 0.00 \\
\hline \multirow{3}{*}{6} & $\mathrm{HCl}$ & 3.70 & 3.70 & 1.70 & 6.00 \\
\cline { 2 - 6 } & $\mathrm{NaOH}$ & 0.01 & 0.01 & 0.01 & 0.01 \\
\cline { 2 - 6 } & $\mathrm{H}_{2} \mathrm{O}$ & 0.00 & 0.00 & 0.00 & 0.00 \\
\hline \multirow{3}{*}{7} & $\mathrm{HCl}$ & 1.00 & 1.00 & 0.99 & 1.00 \\
\cline { 2 - 6 } & $\mathrm{NaOH}$ & 0.00 & 0.00 & 0.00 & 0.00 \\
\cline { 2 - 6 } & $\mathrm{H}_{2} \mathrm{O}$ & 0.00 & 0.00 & 0.00 & 0.00 \\
\hline \multirow{4}{*}{} & & & & & \multicolumn{2}{c|}{ Glass-Ceramic } \\
\hline
\end{tabular}

Table 4. Weight loss $\%$ of the studied glasses and their glass-ceramic derivatives after immersion in different leaching solutions at $95^{\circ} \mathrm{C}$ for $1 \mathrm{hr}$.

\begin{tabular}{|c|c|c|c|c|c|c|}
\hline \multirow{2}{*}{$\begin{array}{c}\text { Sample } \\
\text { No. }\end{array}$} & \multicolumn{3}{|c|}{ Glass } & \multicolumn{3}{c|}{ Glass-Ceramic } \\
\cline { 2 - 7 } & $\begin{array}{c}\mathbf{0 . 1 N} \\
\mathbf{H C l}\end{array}$ & $\begin{array}{c}\mathbf{0 . 1} \mathbf{~ N} \\
\mathbf{N a O H}\end{array}$ & $\mathbf{H}_{\mathbf{2}} \mathbf{O}$ & $\begin{array}{c}\mathbf{0 . 1 N} \\
\mathbf{H C l}\end{array}$ & $\begin{array}{c}\mathbf{0 . 1} \mathbf{~ N} \\
\mathbf{N a O H}\end{array}$ & $\mathbf{H}_{\mathbf{2}} \mathbf{O}$ \\
\hline 1 & 13.01 & 0.013 & 0.02 & 9.04 & 0.01 & 0.00 \\
\hline 2 & 13.39 & 0.015 & 0.04 & 11.41 & 0.01 & 0.00 \\
\hline 3 & 8.44 & 0.099 & 0.10 & 6.37 & 0.00 & 0.00 \\
\hline 4 & 4.08 & 0.012 & 0.04 & 2.75 & 0.00 & 0.00 \\
\hline 5 & 1.46 & 0.009 & 0.02 & 1.00 & 0.00 & 0.00 \\
\hline 6 & 0.06 & 0.006 & 0.02 & 0.01 & 0.00 & 0.00 \\
\hline 7 & 0.03 & 0.001 & 0.02 & 0.01 & 0.00 & 0.00 \\
\hline
\end{tabular}


Table 5. Weight loss \% of the glass and glass-ceramics No.1 and No.7 after being immersed in deionized water and irradiated

\begin{tabular}{|c|c|c|c|c|}
\hline Glass sample & $20 \mathrm{kGy}$ & $40 \mathrm{kGy}$ & $65 \mathrm{kGy}$ & $105 \mathrm{kGy}$ \\
\hline Glass No.1 & 0.732 & 0.772 & 0.785 & 0.785 \\
\hline Glass No.7 & 0.010 & 0.010 & 0.010 & 0.010 \\
\hline Glass-ceramic No.1 & 0.0023 & 0.0047 & 0.0047 & 0.0051 \\
\hline Glass-ceramic No.7 & 0.0019 & 0.0027 & 0.0027 & 0.0030 \\
\hline
\end{tabular}




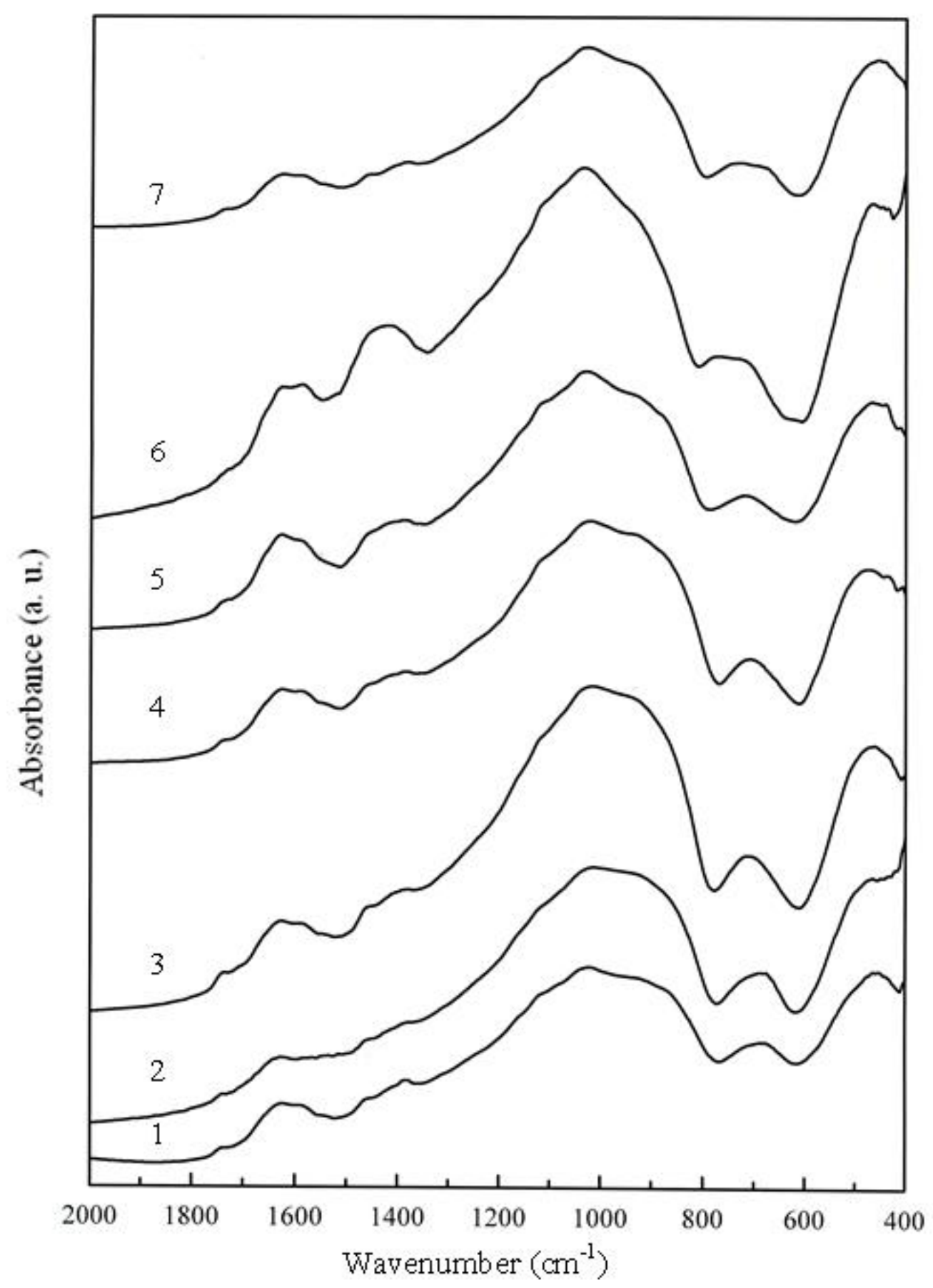

Fig. 3: Infrared absorption spectra of glass samples. 


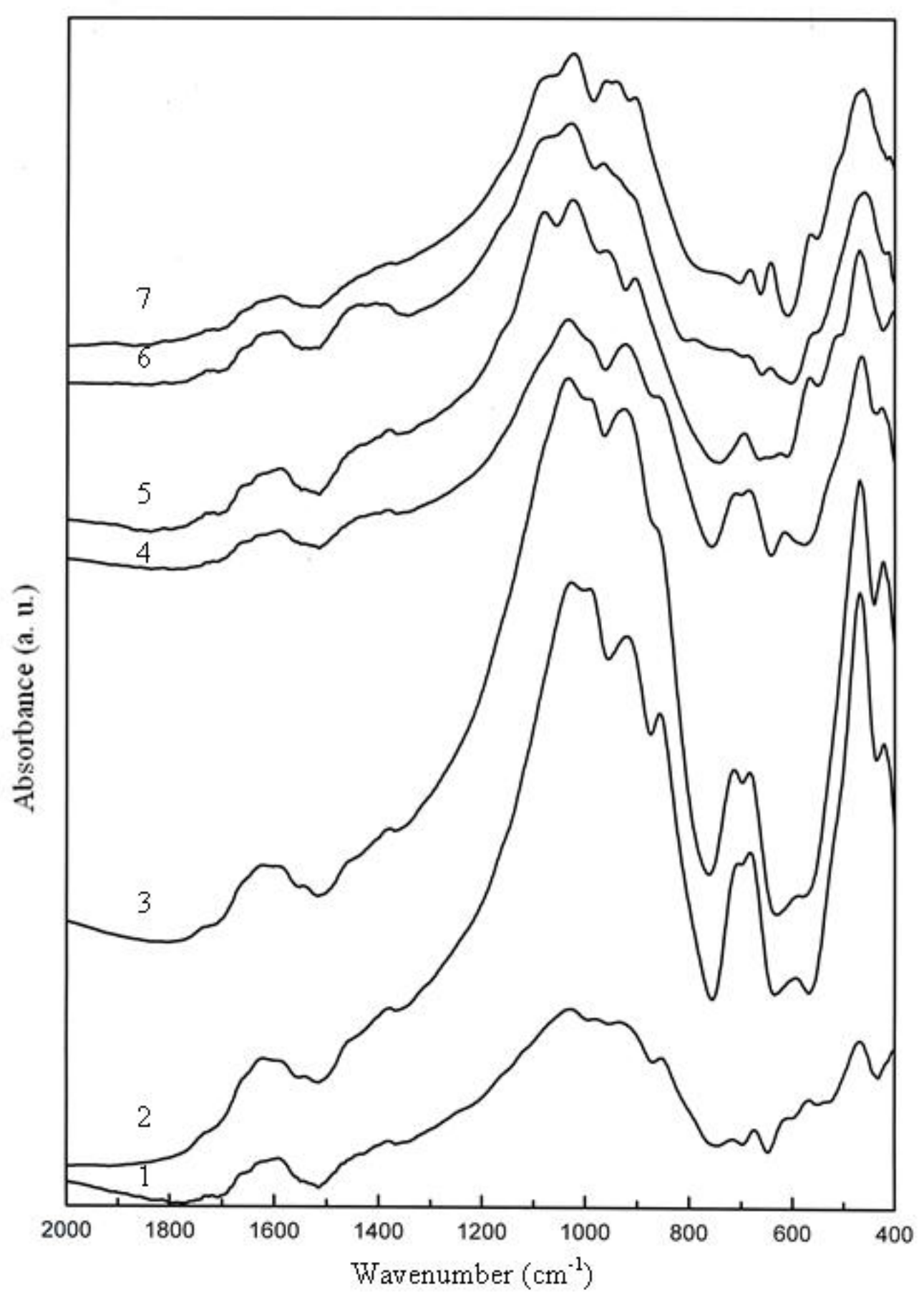

Fig. 4: Infrared absorption spectra of glass-ceramic samples. 


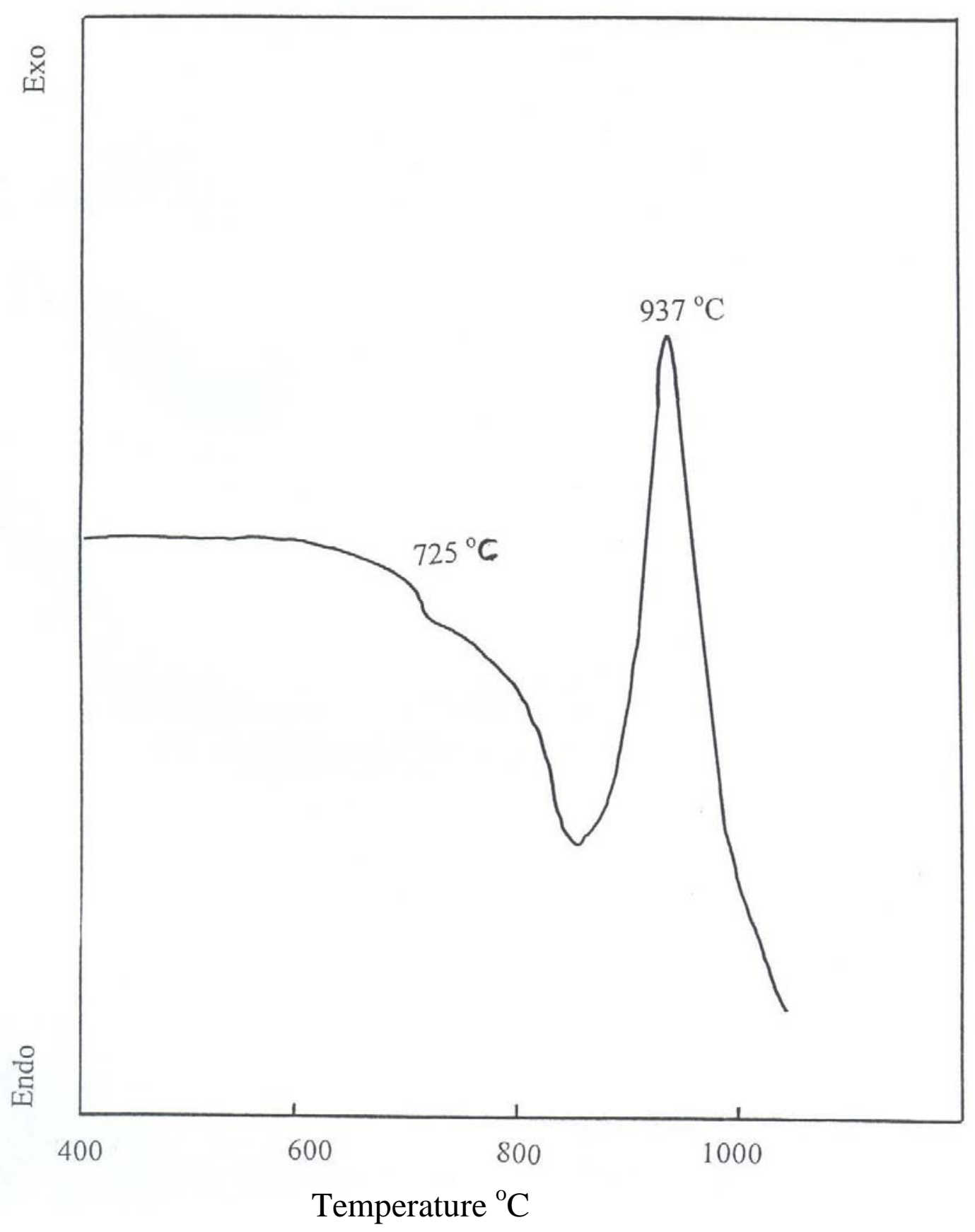

Fig. 1: Differential thermal analysis curve for parent glass. 


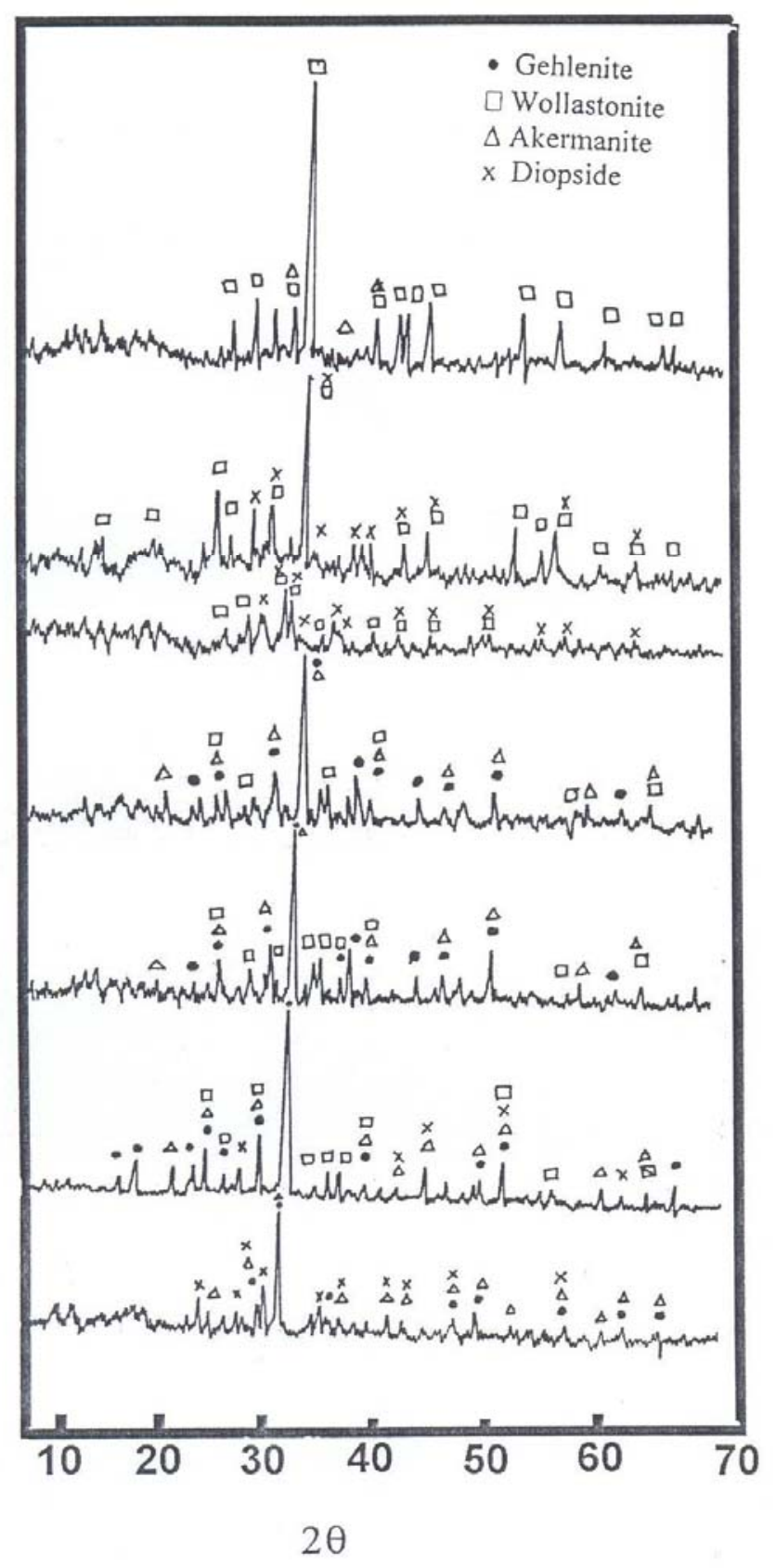

Fig. 2. X-ray diffraction patterns for glass-ceramic samples. 


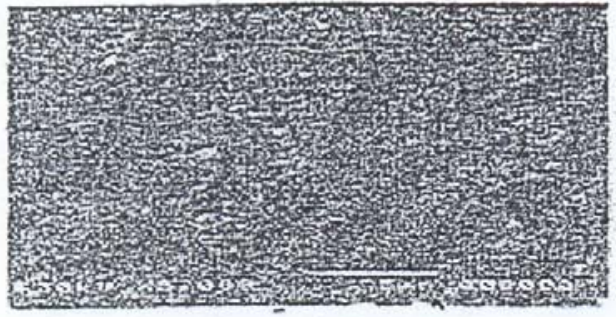

G-1 before

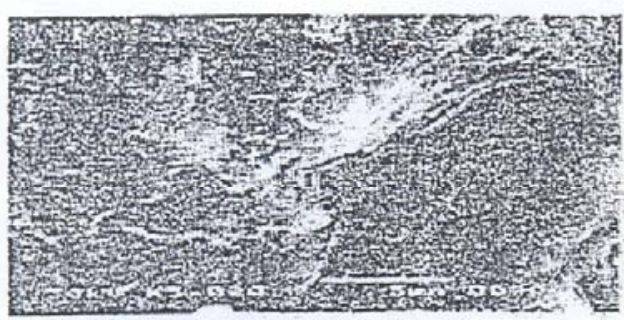

G-7 before

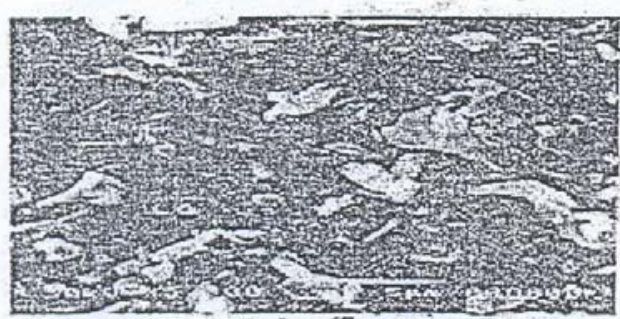

GC-1 before

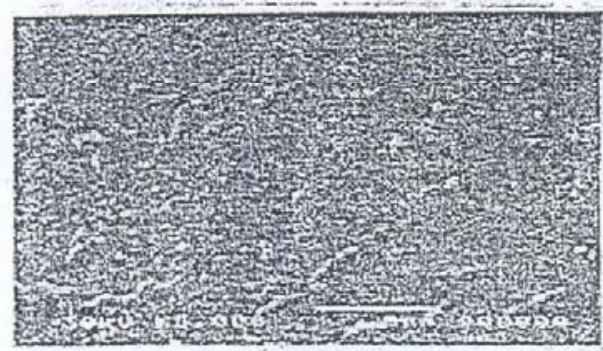

GC-7 before

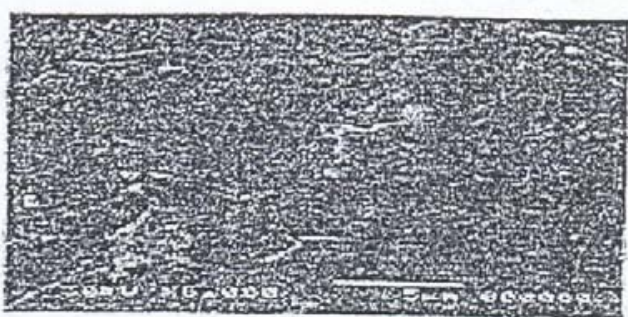

G-1 after

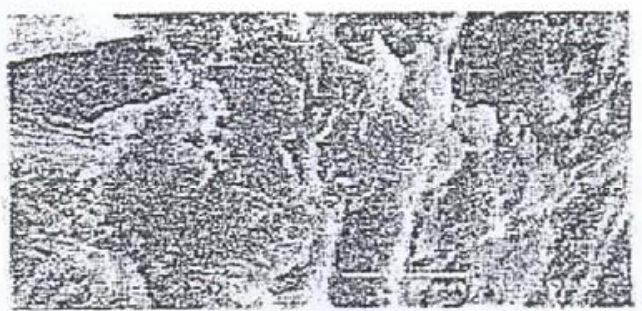

G-7 after

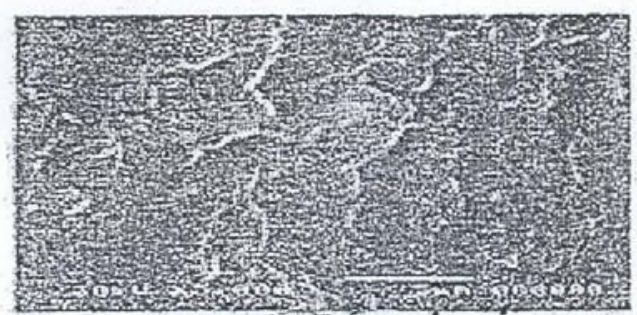

GC-1 after

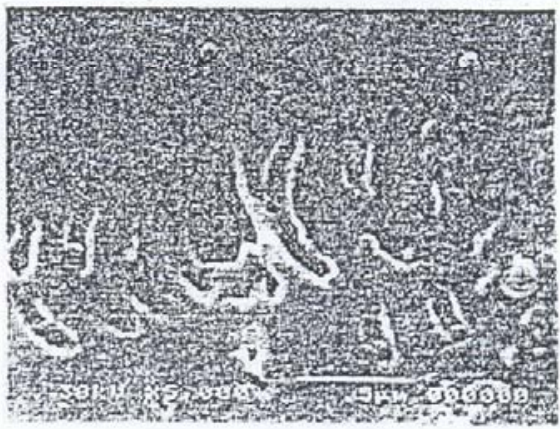

GC-7 after

Fig. 5. Scanning electron microscopic micrographs of glasses and glass-ceramics Nos.

$1 \& 7$ before and after corrosion at irradiated cell. 